\title{
DOES INFLATION TARGETING WORK IN EMERGING COUNTRIES? AN EXAMPLE OF GEORGIA
}

\section{SOPHIO TKESHELASHVILI}

\author{
PhD Student
}

University of Georgia, Georgia

sophio.tkeshelashvili@gmail.com

\section{GIVI LEMONJAVA}

Doctor of Economics, Professor

University of Georgia, Georgia

givi_lemonjava@yahoo.com

\begin{abstract}
Monetary policy is the macroeconomic policy that allows central banks to influence the economy. It involves managing the money supply and interest rates to address macroeconomic challenges such as inflation, consumption, growth and liquidity. Historically, for a long time, the task of monetary policy was limited to controlling the exchange rate, which in turn was fixed (at the beginning of the 20th century on the gold standard) for the purposes of promoting international trade. Eventually such a policy contributed to the Great Depression of the 1930s. After the depression, governments prioritized employment. The central banks have changed their direction based on the relationship between unemployment and inflation, known as the Phillips curve. They believed in the link between unemployment and inflation stability, which is why they decided to use monetary policy (putting money into the economy) to increase total demand and maintain low unemployment. However, this was a misguided decision that led to stagflation in the 1970s and the addition of an oil embargo in 1973. Inflation rose from $5.5 \%$ to $12.2 \%$ in $1970-1979$ and peaked in 1979 at $13.3 \%$. Over the past few decades, central banks have developed a new management technique called «inflation targeting» to control the growth of the overall price index. As part of this practice, central banks are publicizing targeted inflation rate and then, through monetary policy instruments, mainly by changing monetary policy interest rates, trying to bring factual inflation closer to the target. Given that the interest rate and the inflation rate are moving in opposite directions, the measures that the central bank should take by increasing or decreasing the interest rate are becoming more obvious and transparent. One of the biggest advantages of the inflation targeting regime is its transparency and ease of communication with the public, as the pre-determined targets allows the National Bankıs main goal to be precisely defined and form expectations on of monetary policy decisions.

Since 2009, the monetary policy of the National Bank of Georgia has been inflation targeting. The inflation target is determined by the National Bank of Georgia and further approved by the Parliament. Since, 2018-3\% is medium term inflation target of National Bank of Georgia.

The inflation targeting regime also has its challenges, the bigger these challenges are in developing countries. There are studies that prove that in some emerging countries, the inflation targeting regime does not work and other monetary policy regimes are more efficient.

It should be noted that there are several studies on monetary policy and transmission mechanisms in Georgia. Researches made so far around the topic are based on early period data. Monetary policy in the current form with inflation targeting regime started in 2009 and in 2010 monetary policy instruments (refinancing loans, instruments) were introduced accordingly, there are no studies which cover in full the monetary policy rate, monetary policy instruments and their practical usage, path through effect on inflation and economy. It was important to analyze the current monetary policy, its effectiveness, to determine the impact of transmission mechanisms on the small open economy and business development.

The study, conducted on 8 variables using VAR model, identified both significant and weak correlations of the variables outside and within the politics like GDP, inflation, refinancing rate, M3, exchange rate USD/GEL, exchange rate USD/TR and dummy factor, allowing to conclude, that through monetary policy channels and through the tools of the National Bank of Georgia, it is possible to have both direct and indirect (through inflation control) effects on both, economic development and price stability.
\end{abstract}

KEYWORDS: MONETARY POLICY, MONETARY POLICY RATE, INFLATION, INFLATION TARGETING.

For citation: Tkeshelashvili, S., \& Lemonjava, G. (2020). Does Inflation Targeting Work in Emerging Countries? An Example of Georgia. Globalization and Business, 10. 170-179. https://doi.org/10.35945/gb.2020.10.021 


\section{INTRODUCTION:}

Central banks are responsible for the creation and implementation of monetary policy, the stability of the exchange rate, control of monetary aggregates in the economy and ensuring price stability.

Since 2009, the National Bank of Georgia's monetary policy regime has been inflation targeting, likewise in all developed and many developing countries.

Price stability is the mandate of $60 \%$ of countries Central Banks. According to a survey by the Central Bank of Poland (Niedźwiedzińska, 2018), of more than 40 countries with an inflation targeting regime, $14 \%$ have the sole mandate of price stability and $86 \%$ have mixed objectives. From mixed mandates, $52 \%$ prioritize price stability and $33 \%$ do not have explicit priority. Mixed objectives include price stability, economic activity, financial stability and other goals. Price stability is also concerned with maintaining the value of money. Economic activity has a broader interpretation, but it is also concerned with promoting full employment. Financial stability includes supporting the development of the banking system, while other objectives include a stable payment system. Out of 14 inflation targeting countries with no explicit prioritized objective there are 5 developed countries (Australia, Canada, Switzerland, UK, USA) and 9 developing countries (Argentina, Brazil, Chile, Dominican Republic, Guatemala, Paraguay, Russia, Thailand, Uganda). Price stability is a priority for 22 countries ( 8 developed countries and 14 developing countries including Georgia). Among the six countries with the only mandate of price stability are 1 developed country New Zealand and 5 developing countries: Colombia, Kazakhstan, Peru, the Philippines and Romania. After price stability, priority is economic activity, which aims to promote sustainable and full employment. The objective of economic activity is prioritized by 30 countries (12 developed and 18 developing). Financial stability takes second place after economic activity. The financial stability mandate has 23 countries out of which 6 are developed and 17 are developing.

Also, inflation target level is an important factor and according to a survey by the Central Bank of Poland (Niedźwiedzińska, 2018), the developed countries when first establishing the regime set inflation target at $3.8 \%$ on average and now the average target of $2.1 \%$. In developing countries, the initial target was $6 \%$ on average and $4.3 \%$ in the current period.

The main objective of the National Bank of Georgia is price stability, but it also ensures the stable functioning of the financial system if possible so as not to jeopardize its primary objective. There are four main transmission channels: credit channel, exchange rate channel, interest rate channel and expectations channel. Monetary policy instruments include refinancing loans, open market operations, certificates of deposit, treasury securities, overnight loans/deposits and minimum reserve requirements (currently in Georgia: liabilities in national currency $5 \%$ and liabilities in foreign currency 25\%). Depending on the specifics of the country, the transmission of channels and instruments to the economy and their capacity will vary.

Despite the regime has been proven to be the most effective it still has its challenges. In contrary to exchange rate or monetary aggregates, inflation control is not easy. Effect from monetary policy instruments make effect (path through) on inflation only after some lags. Controlling inflation is much difficult in developing counties since, inflation has to be pushed down from high levels. In such circumstance, it is high error probability in inflation forecasts, which results in missing targets. It will be very difficult to build credibility on inflation targeting strategy and hard to explain the reasons of not meeting the targets from monetary authority perspective. It is proven effective strategy, when adoption happens gradually and it is preceded by a decline in inflation (Paul,R.M. Miguel, A.S. Sunil, Sh., 1997). High dollarization may complicate inflation targeting. In many developing countries the balance sheet of companies, households, banks is substantially dollarized, with both assets and liabilities on both sides (Guillermo, 1999). Since, floating exchange rates are required for inflation targeting, fluctuations in the exchange rate are inevitable. However, the large and sharp depreciation of local currency increases the burden of foreign currency denominated debts, which causes a massive deterioration of the balance sheet and increases the risks of financial crisis (Mishkin F. , 1999). Developing countries do not have the luxury of ignoring the exchange rate when conducting monetary policy under the inflation targeting regime, but the role should clearly serve the purposes of inflation. Inflation targeting, especially for dollarized economies, may not be effective until strict prudential regulations and appropriate oversight of financial institutions ensure the stability of the exchange rate shocks.

Today, a more complex policy is being actively pursued, which on the one hand will maximize economic growth and at the same time prevent crises. Some experts have suggested an alternative to inflation targeting, price level targeting or nominal income targeting. Some findings showed that a traditional inflation index fails to fully reflect the problems caused by price changes (Charaia, Papava, 2017; Papava, Charaia, 2018). Experts suggest replacing IT regime with CIT (complex IT) regime (Papava, Charaia, 2019).

As has been already mentioned, monetary policy in the current form with inflation targeting regime started in Georgia in 2009 and in 2010 monetary policy instruments (refinancing loans, instruments) were introduced. The researches made so far are based on early period data (Bakradze, G. and Billmeier, A., 2007), (Alanidi, 2007), (Samkharadze, 2008), (Machavariani, 2012), accordingly, there are no studies which fully cover the monetary policy rate, monetary policy instruments and their current practical usage, path through effect on inflation and economy. It was important to analyze the current monetary policy, its effectiveness, to determine the impact of transmission mechanisms on the small open economy.

\section{Research Methodology and Applied Data}

The methodology and models presented in the paper are fully consistent with the given empirical literature. VAR structuring and performed tests are based on existing studies 
published by IMF and (Vinayagathasan, 2013) on Monetary Policy Transfer Mechanisms. Variables in the model are selected considering the local specifics.

The model includes endogenous vectors

$\left\{Y_{-t}=G D P\right.$, Inf, USE_GEL, RefR, $\left.M 3, M R\right\}$,

which in turn is divided into two parts.

Variables outside of politics

$\left\{Y_{-t}=G D P, \operatorname{Inf}\right\}$ and variables within politics

$Y_{-t}=U S E_{-} G E L, \operatorname{RefR}, M 3, M R .\left\{X_{-t}=U S D_{-} T R, D U M M Y\right\}$

selected as an exogenous vector, given that Turkey is

Georgia ss trading partner it was interesting to find if the dramatic depreciation of the exchange rate (USD/TR) could affect the GEL exchange rate (USD/GEL), inflation or other variables. The DUMMY factor is the 2008 war and the global financial crisis.

Since, only quarterly GDP data available and monthly data were needed to collect sufficient data for analysis, quarterly GDP was converted to monthly GDP via extrapolation method. Finally, monthly GDP (12-month change) from December 2008 to December 2018 was incorporated in the model. The real inflation rate, because it is available on a monthly basis, was included as its 12-month change rates over the full observation period. The USD/GEL exchange rate was used in the model as 12-month change of the average monthly indicators for the full observation period. The refinancing rate indicators of a 12-month change was considered on monthly basis over the full observation period. The 12-month change of the monthly M3 money mass aggregate was used for the full observation period. Turkish Lira exchange rate as exogenous factors was included as the 12-month change of the average monthly indicators for the full observation period. 2008 war and the global financial crisis was applied as "Dummy" factor. In line with expert's recommendations and similar studies, the effect of this variable in this model is given in the period 2008-2010.

The full period of the analysis, cover monthly data for the period from December 2008 to December 2018 (Table 1).

Stationary test, determining the number of lags and robustness of results:

ADF (Augmented Dickey-Fuller) test was performed to find out whether data were stationary or not. For this purpose, each variable was tested and results showed that null hypothesis could not be rejected (except for M3) that means that variables were stationary.

Johansen cointegration test showed cointegration between the variables (Table 2).There are many empirical studies using non-stationary data in VAR model for example: (Kim, Soyoung and Roubini, Nouriel,, 2000), (Citu, 2003), (Sims, C.A. and Zha, T., 1998) (Peersman Gert and Smets Frank, 2001) therefore, variables were used without conversion or other additional filters.

In order to determine the correct lag length, which is a very important part of the model, Likelihood-Ratio (LR), final prediction error (FPE), Schwarzıs Bayesian information criterion (SBIC), Akaikess information criterion (AIC), Hannan and Quinn information criterion (HQIC) were checked. Results showed to choose 8 as lag length criteria (Table 3, Graph 4).

Basic model of VAR including 8 variables on Georgia's economy is illustrated via following equation:

$A(L) Y_{-t}+B(L) X_{-t}=v_{-t}$

Where, $A(L)$ and $B(L)$ are $\mathrm{n} \times \mathrm{n}$ and $\mathrm{n} \times \mathrm{k}$ matrix polynomials and $Y_{-t}$ is $\mathrm{n} \times 1$ endogenous variables vector which can be divided in two blocks: Variables outside the policy and within the policy. Assuming that variables within the policy are under National Bank's control. $X_{-t}$ is $\mathrm{k} \times 1$ vector for exogenous variables and $v_{-t}$ is $\times 1$ structural violation vector where mean is 0 and $\operatorname{VAR}(\mathrm{vt})=\Psi$ ( $\Psi$ diagonal matrix). Structural parameters need to introduce some restrictions on A matrix elements (Vinayagathasan, 2013). However, due to the fact that the model output showed solid and logical results, restrictions were not incorporated, therefore VAR structuring was not performed.

Robustness of results were confirmed by several tests. Darby Watson test results, which is mostly $>2$. VAR Residual tests showed that standard deviations of given autoregression were within the limits. VAR Residual Normality tests (Cholesky Ordering) show that data based on Jarque-Bera results matching a normal distribution (table 9). White Heteroskedasticity tests showed that data used in the model is not heteroscedasticity because probability exceeds $5 \%$ by which null hypothesis was accepted (table10).

\section{Results:}

The Vector Autoregression model identified both significant and weak correlations of the given variables (according to $\mathrm{T}$ statistical and $\mathrm{P}$ value results), summarized results are provided in the Table 5.

Variance-decomposition show how these variables affect each other over time, for example: the monetary policy rate shock for the period of 8 has $43.68 \%$ effect on the fluctuation of the GEL exchange rate and a $4.3 \%$ impact on inflation for period of 5 (See Table N 6).

Variance Decomposition is also a good way to see the Cholesky Ordering in a given period, as shown in Graph N7 / N8.

The study, conducted on 8 variables using VAR, showed the material impact of the monetary policy rate on inflation as well as other material dependences of different variables that allow to conclude that through monetary policy channels and through the tools of the National Bank of Georgia, it is possible to have both direct and indirect (through inflation control) effects, both economic output and price stability. 


\section{REFERENCES}

Aslanidi, O., (2007). The Optimal Monetary Policy and the Channels of Monetary Policy and the Channels of Monetary Transmission Mechanism in CIS-7 Countries: The Case of Georgia, Discussion Paper. 2007, 171 (CERGE-EI)

Bakradze, G., and Billmeier, A., (2007). Inflation targeting in Georgia: Are we there yet? Working Paper, WP/07/193 (International Monetary Fund).

Bank of Canada (2016). Renewal of the Inflation-Control Target.

De Paoli, B., and Paustian, M., (2017). Coordinating Monetary and Macroprudential (Federal Reserve Bank of New York).

Blinder, A., (1982). The Anatomy of Double-Digit Inflation in the 1970s.

Charaia, V., Papava V. (2017). The Role of Inflation and its Targeting for Low-Income Countries (Lessons from Post-Communist Georgia). European Journal of Economic Studies, 6(2). 96-103.

Collard, F., (2017). Optimal Monetary and Prudential Policies. (Macroeconomics.)

Frankel, J., (2012). The death of inflation targeting, retrieved from http://voxeu.org/article/inflation-targeting-dead-long-livenominal-gdp-targeting

Friedman, B.M., and Kuttner, K.N., (1993). Another Look at the Evidence on Money-Income Causality, Journal of Econometrics, 189-203.

Friedman, B.M., (1995). The Rise and Fall of the Money Growth Targets as Guidelines for U.S. Monetary Policy. Bank of Japan Seventh International Conference.

Ghazanchyan, M., (2014). Unraveling the Monetary Policy Transmission Mechanism in Sri Lanka. IMF Working Paper WP/14/190 (Asia and Pacific Department, International Monetary Fund).

Hall, R., and Mankiw, G., (1994). Nominal Income Targeting in N.G. Mankiw (ed.), Monetary Policy. NBER Working Paper, 7193 (Chicago: University of Chicago Press).

Lemonjava, G., (2016). The Transmission Mechanism of Monetary Policy. Globalization and Business, 2, 81-88.

Machavariani, G., (2012). Transmission Mechanisms of Monetary Policy in Georgia-Evidence from VAR Analysis (Central European University, Department of Economics)

Rubio, M., and Carrasco-Gallego, J., A., (2016). Coordinating Macroprudential Policies within the Euro Area (University of Nottingham and University of Portsmouth).

Mankiw, G.N., and Taylor, M.P., (2007). Macroeconomics (Basingstoke: Palgrave Macmillan).

Marshal, F., (1998). Financial Engineering. Moscow M. INFR-M,1998.

Mishkin, F.S, (1999). Lessons from the International Experience (Princeton, NJ: Princeton University Press).

Mishkin, F.S, (2004). Can Inflation Targeting Work in Emerging Market Countries? (Graduate School of Business, Columbia University, and National Bureau of Economic Research).

National Bank of Georgia, (2019). Macroprudential Policy Strategy.

National Bank of Georgia, (2019). Monetary Policy Operations Manual. Retrieved from https://www.nbg.gov.ge/index. php?m=720

National Bank of Georgia (FSI), Financial Soundness Indicators. Retrieved from https://www.nbg.gov.ge/index.php?m=304

Papava, V. Charaia, V. (2018). Agflation and other modifications of inflation (the cases of Georgia and its neighboring countries). Annals of Agrarian Science. 16(2), 201-205.

Papava, V. Charaia, V. (2019). On Complex Inflation Targeting and Modified Inflation Indicators (Experience of Georgia). International Finance. 23(3), 16-34.

Samkharadze, B., (2008). Monetary Transmission Mechanism in Georgia: Analyzing Pass-Through of Different Channels (Center for Operations Research and Econometrics, Belgium)

Sarwat, J., Inflation Targeting: Holding the Line. Retrieved from http://www.imf.org/external/pubs/ft/fandd/basics/target. htm

Vinayagathasan, T., (2013). Monetary Policy and the Real Economy: A Structural VAR Approach for Sri Lanka. GRIPS Discussion Paper, 13-13 (National Graduate Institute for Policy Studies).

Tierne, W., G., and Clemens, R., F., (2011). Qualitative Research and Public Policy: The Challenges of Relevance and Trustworthiness (Center for Higher Education Policy Analysis University of Southern California). 
Annex 1

\section{Tables and Graphs:}

Table 1. Variable analysis used in the model:

\begin{tabular}{|c|c|c|c|c|c|c|c|c|}
\hline & _GDP & ${ }_{-}{ }^{N}{ }_{-}$ & $\begin{array}{c}\text { USD_- } \\
\text { GEL }\end{array}$ & ${ }_{\text {RATE }}^{\text {REF }}$ & _M3 & _MR & _USD_TR & DUMMY \\
\hline Mean & -0.0047 & 0.0341 & 0.0590 & -0.0036 & 0.1643 & 0.1528 & 0.1491 & 0.2066 \\
\hline Median & 0.0036 & 0.0276 & 0.0356 & 0.0000 & 0.1698 & 0.1513 & 0.1290 & 0.0000 \\
\hline Maximum & 0.0989 & 0.1433 & 0.3739 & 0.0400 & 0.4659 & 0.3373 & 0.8359 & 1.0000 \\
\hline Minimum & -0.1617 & -0.0330 & -0.1093 & -0.0600 & -0.1697 & -0.0575 & -0.1034 & 0.0000 \\
\hline Std. Dev. & 0.0509 & 0.0365 & 0.1020 & 0.0211 & 0.0977 & 0.0794 & 0.1493 & 0.4066 \\
\hline Skewness & -0.8104 & 0.8675 & 1.2274 & -0.3911 & -0.5472 & -0.4352 & 1.2319 & 1.4493 \\
\hline Kurtosis & 4.5252 & 3.9001 & 4.4003 & 3.5340 & 5.9970 & 3.8098 & 6.2944 & 3.1004 \\
\hline Jarque-Bera & $\begin{array}{c}24.970 \\
5\end{array}$ & 19.2634 & 40.2697 & 4.5221 & 51.322 & 7.12516 & 85.326 & 42.409 \\
\hline Probability & 0.0000 & 0.0001 & 0.0000 & 0.1042 & 0.0000 & 0.0283 & 0.0000 & 0.0000 \\
\hline Sum & -0.5743 & 4.1356 & 7.1388 & -0.4350 & 19.885 & 18.487 & 18.046 & 25.000 \\
\hline $\begin{array}{l}\text { Sum Sq. } \\
\text { Dev. }\end{array}$ & 0.3110 & 0.1601 & 1.2485 & 0.0535 & 1.1439 & 0.7562 & 2.6750 & 19.835 \\
\hline Observations & 121 & 121 & 121 & 121 & 121 & 121 & 121 & 121 \\
\hline
\end{tabular}

Table 2. Johansen cointegration test output:

Date: 02/07/20 Time: 11:18

Sample (adjusted): 2009M09 2018M12

Included observations: 112 after adjustments

Trend assumption: Quadratic deterministic trend

Series:_GDP_INF_REF_RATE_USD_GEL_M3 _MR

Exogenous series:_U্SD_TR DUMMYY

Warning: Critical values assume no exogenous series

Lags interval (in first differences): 1 to 8

\begin{tabular}{ccccc}
\hline \hline \multicolumn{2}{l}{ Unrestricted Cointegration Rank Test (Trace) } & & \\
\hline \hline $\begin{array}{l}\text { Hypothesized } \\
\text { No. of CE }(\mathrm{s})\end{array}$ & Eigenvalue & $\begin{array}{c}\text { Trace } \\
\text { Statistic }\end{array}$ & $\begin{array}{c}0.05 \\
\text { Critical Value }\end{array}$ & Prob.** \\
\hline \hline None * & 0.461814 & 204.3518 & 107.3466 & 0.0000 \\
At most 1 & 0.422554 & 134.9620 & 79.34145 & 0.0000 \\
At most 2* & 0.318144 & 73.45841 & 55.24578 & 0.0006 \\
At most 3 & 0.168409 & 30.56942 & 35.01090 & 0.1383 \\
At most 4 & 0.083574 & 9.914956 & 18.39771 & 0.4887 \\
At most 5 & 0.001252 & 0.140334 & 3.841466 & 0.7079 \\
\hline \hline
\end{tabular}

Trace test indicates 3 cointegrating eqn(s) at the 0.05 level

* denotes rejection of the hypothesis at the 0.05 level

**MacKinnon-Haug-Michelis (1999) p-values

Unrestricted Cointegration Rank Test (Maximum Eigenvalue) 
Table 3. Determination of Lag Length:

VAR Lag Order Selection Criteria

Endogenous variables:_GDP_INF__REF_RATE_USD_GEL_M3 _MR

Exogenous variables: $\mathrm{C}_{-}^{-} \mathrm{USD}_{-}{ }_{-} \mathrm{TR} \overline{\mathrm{DU}} \overline{\mathrm{U}} \mathrm{MMY}$

Date: $02 / 06 / 20$ Time: $23: 19$

Sample: 2008M12 2018M12

Included observations: 113

\begin{tabular}{ccccccc}
\hline \hline Lag & LogL & LR & FPE & AIC & SC & HQ \\
\hline \hline 0 & 1305.524 & NA & $5.11 \mathrm{e}-18$ & -22.78803 & -22.35358 & -22.61174 \\
1 & 2121.214 & 1501.448 & $5.20 \mathrm{e}-24$ & -36.58787 & -35.28451 & -36.05898 \\
2 & 2288.505 & 290.1686 & $5.13 \mathrm{e}-25$ & -38.91160 & $-36.73935^{*}$ & $-38.03012^{*}$ \\
3 & 2321.328 & 53.44493 & $5.52 \mathrm{e}-25$ & -38.85536 & -35.81420 & -37.62129 \\
4 & 2355.958 & 52.71177 & $5.83 \mathrm{e}-25$ & -38.83112 & -34.92106 & -37.24445 \\
5 & 2408.311 & 74.12852 & $4.58 \mathrm{e}-25$ & -39.12055 & -34.34159 & -37.18130 \\
6 & 2460.808 & 68.75705 & $3.68 \mathrm{e}-25$ & -39.41254 & -33.76467 & -37.12069 \\
7 & 2506.984 & 55.57402 & $3.40 \mathrm{e}-25$ & -39.59263 & -33.07586 & -36.94820 \\
8 & 2567.088 & $65.95550^{*}$ & $2.56 \mathrm{e}-25^{*}$ & $-40.01926^{*}$ & -32.63359 & -37.02223 \\
\hline \hline
\end{tabular}

* indicates lag order selected by the criterion

LR: sequential modified LR test statistic (each test at $5 \%$ level)

FPE: Final prediction error

AIC: Akaike information criterion

SC: Schwarz information criterion

HQ: Hannan-Quinn information criterion

Graph 4. Inverse Roots of AR Characteristic Polynomial

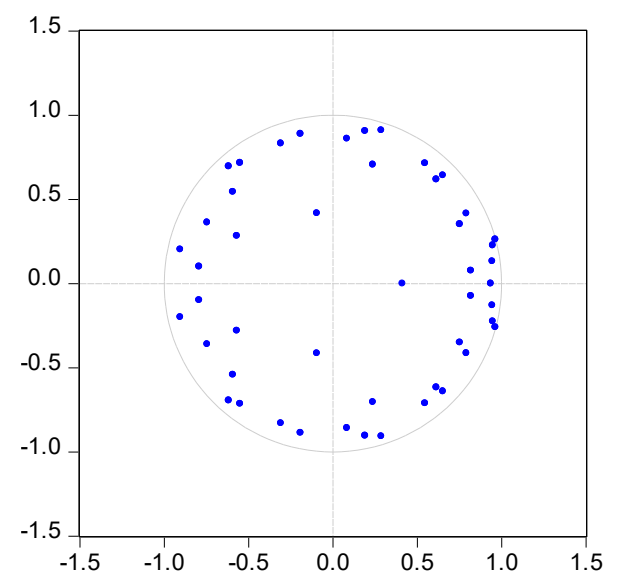

Table N5

Vector Autoregression model output summary:

\begin{tabular}{llll} 
Dependent Variables & Independent Variables & Sign & Dependence Level \\
\hline GDP & INF & $(-)$ & Highly Significant \\
GDP & M3 & $(+)$ & Highly Significant \\
GDP & MR & $(-)$ & Highly Significant \\
GDP & USD_GEL & $(-)$ & Significant \\
GDP & $(-)$ & N/A \\
INF & Dummy & $(-)$ & Highly Significant \\
INF & REF_RATE & $(+)$ & Highly Significant \\
INF & USD_GEL & $(+)$ & Highly Significant \\
INF & M3 & $(-)$ & Highly Significant \\
INF & MR & $(+)$ & Highly Significant \\
INF & TR_USD & $(-)$ & N/A \\
USD_GEL & Dummy & $(+)$ & Highly Significant \\
USD_GEL & INF & $(-)$ & Highly Significant \\
USD_GEL & REF_RATE & $(+)$ & Highly Significant \\
USD_GEL & TR_USD & $(+)$ & Weak \\
USD_GEL & M3 & $(-)$ & Weak
\end{tabular}


Table 6.

\begin{tabular}{|c|c|c|c|c|c|c|c|}
\hline \multicolumn{8}{|c|}{ Variance Decomposition of_GDP: } \\
\hline Period & S.E. & _GDP & $\mathrm{INF}_{-}$ & _REF_RATE & _USD_GEL & _M3 & -MR \\
\hline 1 & 0.0030 & 100.0000 & 0.0000 & 0.0000 & 0.0000 & 0.0000 & 0.0000 \\
\hline 2 & 0.0056 & 96.2869 & 1.2995 & 0.1095 & 0.2804 & 0.5352 & 1.4884 \\
\hline 3 & 0.0077 & 90.7635 & 0.7401 & 0.5841 & 0.3830 & 4.3655 & 3.1638 \\
\hline 4 & 0.0092 & 86.0893 & 0.5898 & 1.9912 & 0.3119 & 8.3712 & 2.6465 \\
\hline 5 & 0.0104 & 79.3452 & 1.6999 & 3.4396 & 0.3619 & 12.962 & 2.1912 \\
\hline 6 & 0.0113 & 74.7741 & 3.2616 & 3.6221 & 0.5956 & 15.616 & 2.1305 \\
\hline 7 & 0.0121 & 71.3043 & 5.4457 & 3.4307 & 0.8487 & 17.059 & 1.9116 \\
\hline 8 & 0.0129 & 67.0644 & 8.3445 & 3.0060 & 1.1884 & 18.694 & 1.7027 \\
\hline
\end{tabular}

\begin{tabular}{|c|c|c|c|c|c|c|c|}
\hline \multicolumn{8}{|c|}{ Variance Decomposition of INF_: } \\
\hline Period & S.E. & $\overline{-}_{\mathrm{GDP}}$ & INF_ & _REF_RATE & _USD_GEL & _M3 & -MR \\
\hline 1 & 0.0083 & 1.4481 & 98.5519 & 0.0000 & 0.0000 & 0.0000 & 0.0000 \\
\hline 2 & 0.0124 & 0.6478 & 94.6794 & 0.5758 & 0.1662 & 3.9301 & 0.0007 \\
\hline 3 & 0.0147 & 1.8914 & 79.0173 & 0.6753 & 1.0024 & 8.0028 & 9.4108 \\
\hline 4 & 0.0170 & 8.0832 & 60.9304 & 0.5674 & 3.3633 & 11.0298 & 16.026 \\
\hline 5 & 0.0192 & 8.6643 & 48.4467 & 0.8662 & 4.7300 & 16.2408 & 21.0518 \\
\hline 6 & 0.0208 & 8.6639 & 41.6264 & 1.0710 & 4.9433 & 15.3298 & 28.3656 \\
\hline 7 & 0.0227 & 8.4798 & 35.0436 & 3.58322 & 9.2566 & 13.2827 & 30.3541 \\
\hline 8 & 0.0241 & 8.6327 & 31.3477 & 4.86332 & 12.7484 & 11.8596 & 30.5483 \\
\hline
\end{tabular}

Variance Decomposition of_REF_RATE:

\begin{tabular}{|c|c|c|c|c|c|c|c|}
\hline Period & S.E. & _ $\overline{\mathrm{GDP}}$ & INF_ $_{-}$ & _REF_RATE & _USD_GEL & _M3 & _MR \\
\hline 1 & 0.0023 & $3.87 \mathrm{E}-05$ & 2.9664 & 97.0336 & 0.0000 & 0.0000 & 0.0000 \\
\hline 2 & 0.0031 & 3.4064 & 1.6405 & 84.6393 & 8.2586 & 1.9345 & 0.1209 \\
\hline 3 & 0.0038 & 4.4754 & 3.8689 & 70.7132 & 14.4522 & 3.2013 & 3.2891 \\
\hline 4 & 0.0044 & 3.5796 & 3.1153 & 65.2877 & 18.3349 & 6.2531 & 3.4293 \\
\hline 5 & 0.0052 & 2.5712 & 4.3127 & 55.2950 & 23.3934 & 11.6556 & 2.7721 \\
\hline 6 & 0.0060 & 2.5463 & 3.2115 & 49.7057 & 30.8335 & 11.1552 & 2.5477 \\
\hline 7 & 0.0069 & 1.9911 & 2.5690 & 44.3941 & 36.4999 & 11.2570 & 3.2887 \\
\hline 8 & 0.0078 & 1.8649 & 3.2317 & 37.8602 & 43.6823 & 10.7414 & 2.6195 \\
\hline
\end{tabular}

\begin{tabular}{|c|c|c|c|c|c|c|c|}
\hline \multicolumn{8}{|c|}{ Variance Decomposition of USD GEL: } \\
\hline Period & S.E. & GDP & _INF_ & _REF_RATE & _USD_GEL & _M3 & -MR \\
\hline 1 & 0.0264 & 0.1116 & 0.1686 & 21.6967 & 78.0231 & 0.0000 & 0.0000 \\
\hline 2 & 0.0433 & 0.4486 & 1.9873 & 23.0373 & 72.2301 & 1.9074 & 0.3893 \\
\hline 3 & 0.0570 & 1.0670 & 7.3603 & 23.5841 & 66.2462 & 1.51715 & 0.2253 \\
\hline 4 & 0.0664 & 1.0366 & 10.6550 & 20.7358 & 65.8273 & 1.38916 & 0.3561 \\
\hline 5 & 0.0730 & 2.8907 & 13.3169 & 18.2009 & 64.0152 & 1.15003 & 0.4263 \\
\hline 6 & 0.0798 & 4.4666 & 14.8546 & 15.4596 & 63.4629 & 1.34897 & 0.4074 \\
\hline 7 & 0.0873 & 4.1922 & 16.4709 & 13.3018 & 62.4632 & 2.53767 & 1.0342 \\
\hline 8 & 0.0925 & 3.7380 & 19.4277 & 11.9290 & 58.7645 & 4.20428 & 1.9365 \\
\hline
\end{tabular}

Variance Decomposition of_M3:

\begin{tabular}{cccccccc} 
Period & S.E. & - GDP & ${ }_{-}$INF & ${ }_{-}$REF_RATE & _USD_GEL & ${ }_{-}$M3 & \multirow{2}{*}{ MR } \\
\hline \hline 1 & 0.0328 & $3.40 \mathrm{E}-05$ & 0.9233 & 18.2190 & 14.2497 & 66.6079 & 0.0000 \\
2 & 0.0406 & 2.2670 & 1.1717 & 25.7915 & 17.7641 & 52.9290 & 0.0770 \\
3 & 0.0447 & 4.86678 & 0.9842 & 24.2250 & 18.2965 & 51.2979 & 0.3296 \\
4 & 0.0470 & 5.2738 & 1.8413 & 22.8830 & 17.3207 & 50.1040 & 2.5774 \\
5 & 0.0476 & 5.2590 & 2.0434 & 22.4348 & 18.1435 & 48.9592 & 3.1600 \\
6 & 0.0482 & 5.1479 & 2.7318 & 22.8127 & 18.0848 & 48.1442 & 3.0786 \\
7 & 0.0487 & 5.0673 & 2.9715 & 23.0757 & 18.3898 & 47.2543 & 3.2414 \\
8 & 0.0493 & 4.9538 & 3.3685 & 22.5319 & 18.0600 & 46.1859 & 4.8998 \\
\hline \hline
\end{tabular}


Variance Decomposition of_MR:

\begin{tabular}{|c|c|c|c|c|c|c|c|}
\hline Period & S.E. & _GDP & INF$_{-}$ & _REF_RATE & _USD_GEL & _M3 & _MR \\
\hline 1 & 0.0053 & 0.1974 & 0.6684 & 2.8578 & 11.3209 & 0.8070 & 84.1485 \\
\hline 2 & 0.0104 & 0.3352 & 1.2652 & 3.4738 & 11.6119 & 1.4010 & 81.9128 \\
\hline 3 & 0.0153 & 0.5319 & 0.7849 & 6.5200 & 10.724 & 3.7017 & 77.7377 \\
\hline 4 & 0.0194 & 0.5423 & 0.5096 & 12.4125 & 8.0522 & 7.7251 & 70.7583 \\
\hline 5 & 0.0231 & 0.8415 & 0.3995 & 18.5483 & 6.2327 & 10.9869 & 62.9911 \\
\hline 6 & 0.0260 & 1.2431 & 0.4926 & 23.7044 & 5.3399 & 12.7971 & 56.4228 \\
\hline 7 & 0.028352 & 1.443491 & 0.697125 & 27.99507 & 4.719161 & 13.82132 & 51.32384 \\
\hline 8 & 0.029907 & 1.580240 & 0.910831 & 30.94373 & 4.293370 & 14.49912 & 47.77272 \\
\hline
\end{tabular}

Cholesky Ordering:_GDP_INF__REF_RATE__USD_GEL_M3_MR

Graph 7.

Response to Cholesky One S.D. (d.f. adjusted)Innovations \pm 2 S.E.

Response of _REF_RATE to__USE_GEL

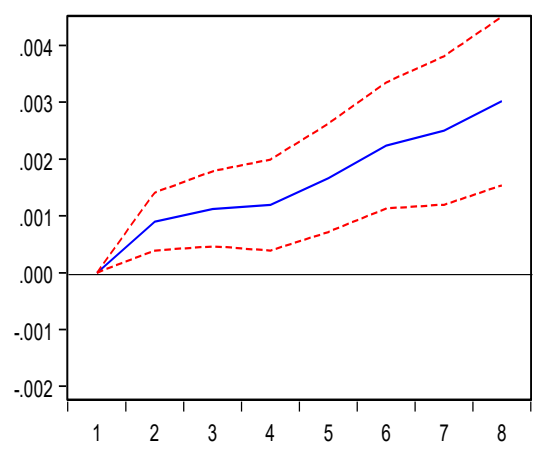

Response of _M3 to_USE_GEL

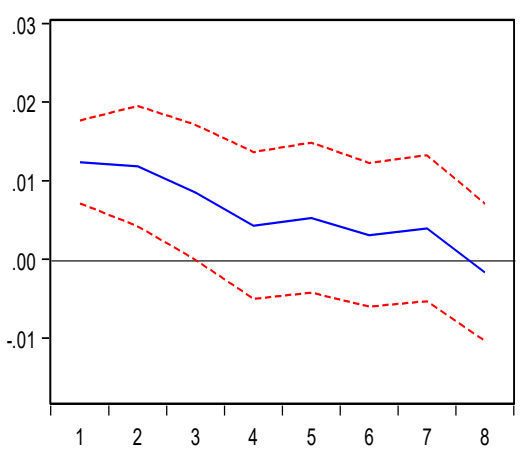

Response of_MR to_USE_GEL

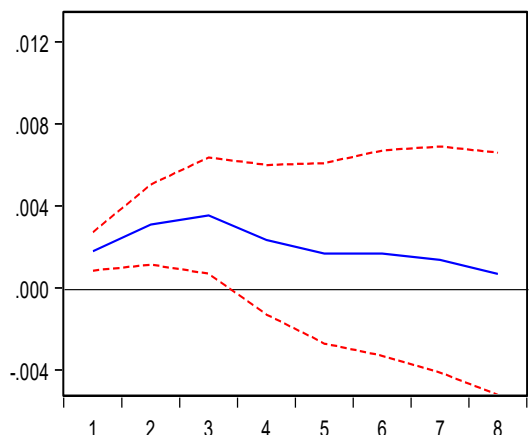

Response of_REF_RATE to_M3

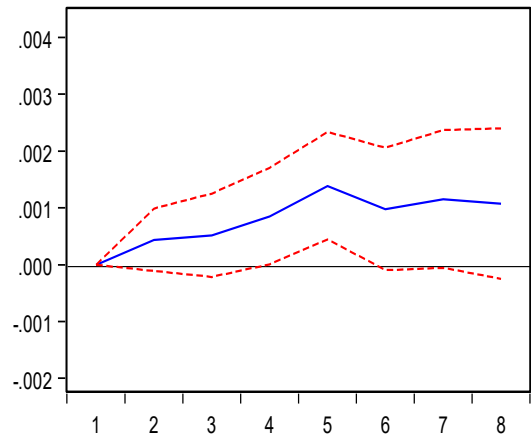

Response of _M3 to _M3

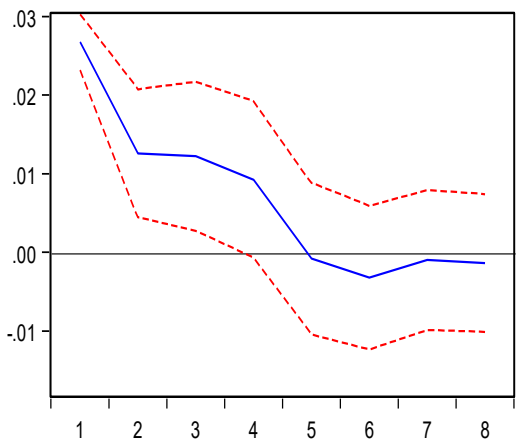

Response of_MR to_M3

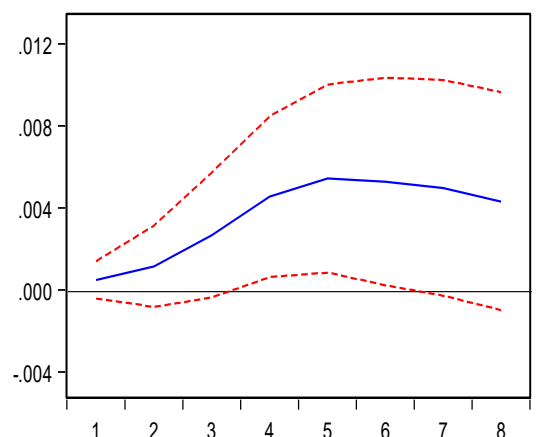

Response of _REF_RATE to_MR

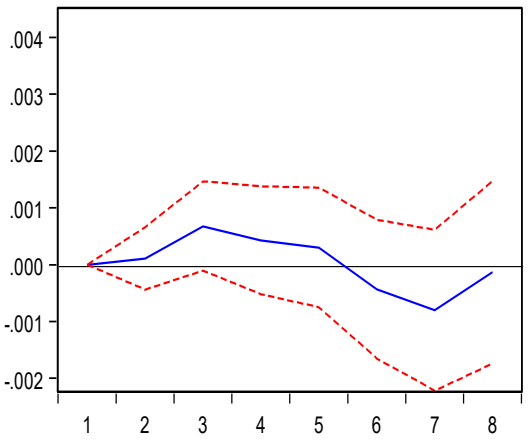

Response of _M3 to _MR

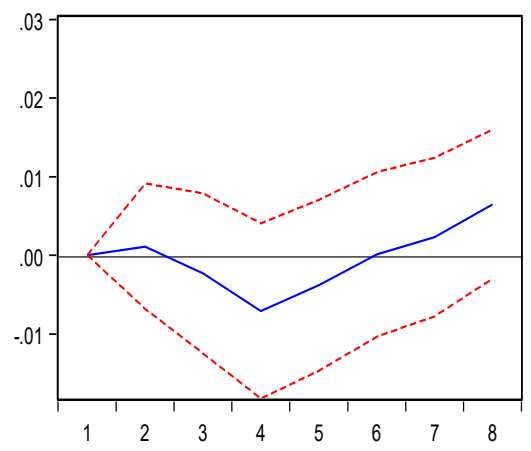

Response of _MR to _MR

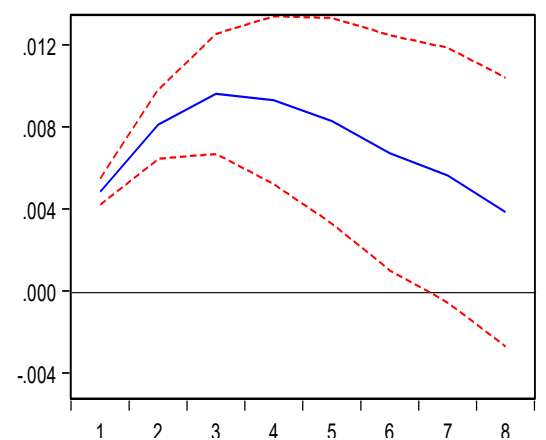


Graph 8.

Response to Cholesky One S.D. (d.f. adjusted) Innovations \pm 2 S.E.

Response of_GDP to_INF_

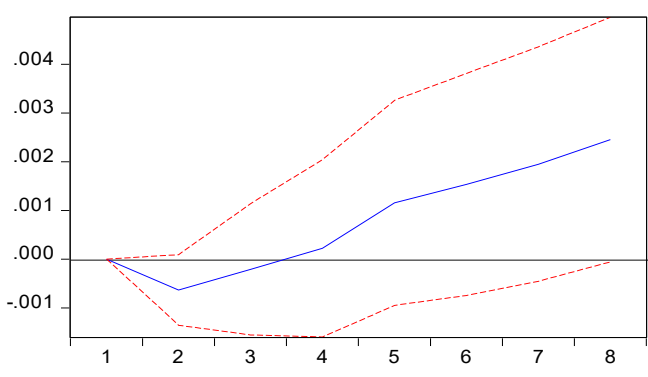

Response of_USE_GEL to _INF_

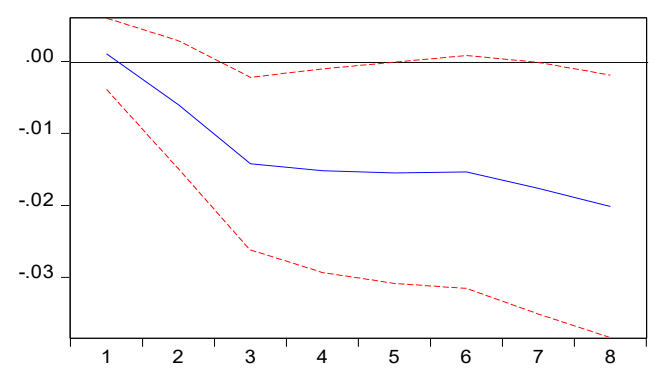

Response of_MR to_INF_

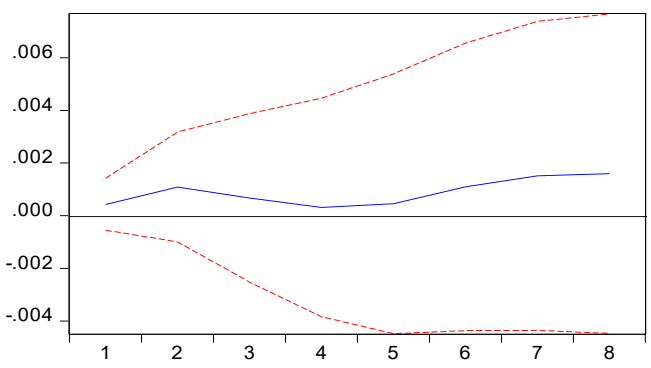

Response of_REF_RATE to _INF_

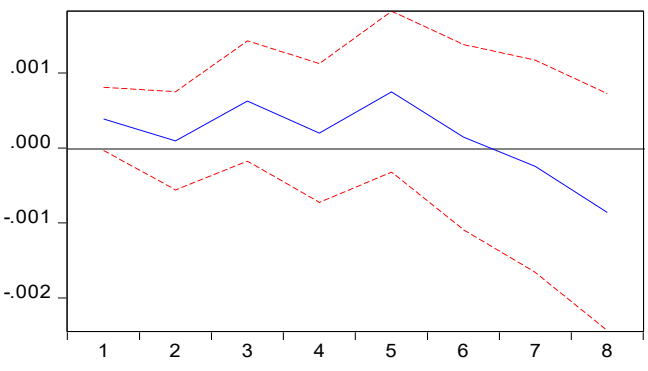

Response of_M3 to_INF_

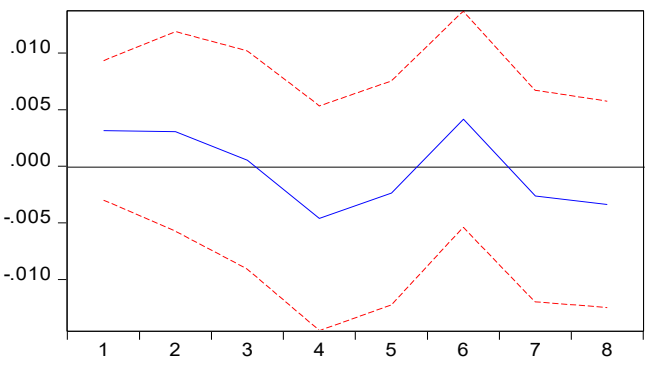

Table 9. VAR Residual Normality Tests

Orthogonalization: Cholesky (Lutkepohl)

Null Hypothesis: Residuals are multivariate normal

Date: 02/06/20 Time: 23:30

Sample: 2008M12 2018M12

Included observations: 113

\begin{tabular}{ccccc}
\hline \hline Component & Skewness & Chi-sq & Df & Prob.* \\
\hline \hline 1 & 0.041307 & 0.032134 & 1 & 0.8577 \\
2 & 0.057996 & 0.063346 & 1 & 0.8013 \\
3 & 0.038903 & 0.028503 & 1 & 0.8659 \\
4 & -0.358232 & 2.416888 & 1 & 0.1200 \\
5 & -0.195815 & 0.722135 & 1 & 0.3954 \\
6 & -0.054128 & 0.055180 & 1 & 0.8143 \\
\hline \hline Joint & & 3.318185 & 6 & 0.7680 \\
\hline \hline Component & Kurtosis & Chi-sq & Df & Prob. \\
\hline 1 & 4.635807 & 12.59887 & 1 & 0.0004 \\
3 & 2.479903 & 1.273610 & 1 & 0.2591 \\
4 & 3.108690 & 0.055622 & 1 & 0.8136 \\
5 & 3.645400 & 1.961212 & 1 & 0.1614 \\
6 & 3.333067 & 0.522313 & 1 & 0.4699 \\
\hline \hline Joint & 2.546416 & 0.968687 & 1 & 0.3250 \\
\hline \hline
\end{tabular}




\begin{tabular}{cccc} 
Component & Jarque-Bera & Df & Prob. \\
\hline \hline 1 & 12.63100 & 2 & 0.0018 \\
2 & 1.336956 & 2 & 0.5125 \\
3 & 0.084124 & 2 & 0.9588 \\
4 & 4.378100 & 2 & 0.1120 \\
5 & 1.244448 & 2 & 0.5367 \\
6 & 1.023867 & 2 & 0.5993 \\
\hline \hline Joint & 20.69850 & 12 & 0.0550 \\
\hline \hline
\end{tabular}

*Approximate p-values do not account for coefficient Estimation

Table 10. VAR Residual Heteroskedasticity Tests (Levels and Squares)

Date: 02/06/20 Time: 23:32

Sample: 2008M12 2018M12

Included observations: 113

\begin{tabular}{|c|c|c|c|c|c|}
\hline \multicolumn{3}{|l|}{ Joint test: } & & & \\
\hline Chi-sq & $\mathrm{df}$ & Prob. & & & \\
\hline 2085.981 & 2079 & 0.4528 & & & \\
\hline \multicolumn{6}{|c|}{ Individual components: } \\
\hline Dependent & R-squared & $F(99,13)$ & Prob. & Chi-sq(99) & Prob. \\
\hline res1*res1 & 0.873213 & 0.904388 & 0.6367 & 98.67311 & 0.4904 \\
\hline res $2 *$ res 2 & 0.909176 & 1.314482 & 0.3011 & 102.7369 & 0.3785 \\
\hline res3*res3 & 0.905782 & 1.262395 & 0.3332 & 102.3533 & 0.3886 \\
\hline res4*res4 & 0.770752 & 0.441487 & 0.9882 & 87.09499 & 0.7980 \\
\hline res $5 *$ res 5 & 0.885107 & 1.011606 & 0.5318 & 100.0171 & 0.4525 \\
\hline res6*res6 & 0.937103 & 1.956427 & 0.0870 & 105.8926 & 0.2994 \\
\hline res2*res1 & 0.861711 & 0.818240 & 0.7248 & 97.37329 & 0.5274 \\
\hline res3*res1 & 0.889757 & 1.059807 & 0.4881 & 100.5425 & 0.4379 \\
\hline res3*res2 & 0.889784 & 1.060108 & 0.4878 & 100.5456 & 0.4378 \\
\hline res4*res1 & 0.889426 & 1.056245 & 0.4912 & 100.5051 & 0.4389 \\
\hline res4*res2 & 0.965741 & 3.701597 & 0.0055 & 109.1287 & 0.2285 \\
\hline res4*res3 & 0.845171 & 0.716804 & 0.8248 & 95.50433 & 0.5808 \\
\hline res5*res1 & 0.863658 & 0.831804 & 0.7109 & 97.59337 & 0.5211 \\
\hline res5*res2 & 0.797531 & 0.517245 & 0.9650 & 90.12098 & 0.7268 \\
\hline res5*res3 & 0.854243 & 0.769589 & 0.7739 & 96.52942 & 0.5515 \\
\hline res $5 *$ res 4 & 0.801412 & 0.529920 & 0.9595 & 90.55953 & 0.7157 \\
\hline res6*res1 & 0.882446 & 0.985731 & 0.5563 & 99.71639 & 0.4609 \\
\hline res6*res2 & 0.855321 & 0.776304 & 0.7672 & 96.65127 & 0.5481 \\
\hline res6*res3 & 0.960868 & 3.224362 & 0.0107 & 108.5781 & 0.2398 \\
\hline res6*res4 & 0.914594 & 1.406203 & 0.2516 & 103.3491 & 0.3625 \\
\hline res6*res5 & 0.920330 & 1.516905 & 0.2024 & 103.9973 & 0.3459 \\
\hline
\end{tabular}

